\title{
ANALISA KEKUATAN BENDING KOMPOSIT EPOXY DENGAN PENGUATAN SERAT NILON
}

\author{
Nasmi Herlina Sari*, Sinarep** \\ * Dosen Jurusan Teknik Mesin Universitas Mataram NTB, Jl. Majapahit No 62 Mataram \\ ** Dosen Jurusan Teknik Mesin Universitas Mataram NTB, Jl. Majapahit No 62 Mataram \\ Email: $\underline{\text { nazmi2707@yahoo.com }}$
}

\begin{abstract}
The development of composite materials in the field of engineering is increasingly being used. This is because of its properties are superior compared to conventional materials, as the ratio between strength and density are quite high, stiff, the manufacturing process is very simple and resistant to corrosion and fatigue loads. The purpose of this study was to determine the effect the addition of nylon fibers with Epoxy Matrix on the increase in bending strength of epoxy composites.

The objected of this study was the composite of nylon fiber, which is cut $12 \mathrm{~mm}$ nylon fiber with epoxy resin as a fastening material. Before performing an experiment testing the tensile fibers has done and known to the stress of 461.22 MPa. There are 3 variations of volume fraction In this experiment, those are volume fraction of 40\%, 50\% and $60 \%$, with 3 variation each. Method in the manufacture of specimens with the way the mould press. Tools to test the specimen is bending test machine (servopulser). Specimens using a standard test of ASTM C 393-94. Bending test results showed that the nylon fiber composite with fiber volume fraction $40 \%$ stress of $787.16 \mathrm{MPa}$, modulus of elasticity of $1.06 \mathrm{GPa}$, volume fraction of $50 \%$ the stress of $902.01 \mathrm{MPa}$, modulus of elasticity of $1.08 \mathrm{GPa}$, and for $60 \%$ volume fraction of the stress of $950.02 \mathrm{MPa}$, modulus of elasticity of $0.99 \mathrm{GPa}$.
\end{abstract}

Key Word : Volume fraction, Bending strength, epoxy, nylon

\section{Pendahuluan}

Komposit merupakan material yang bahan utamanya menggunakan bahan plastik, salah satu faktor yang cukup aplikatif dalam dunia engineering adalah dimungkinkannya peningkatan sifat dengan penguat dari plastik. Disamping itu plastik juga memiliki sifat ketahanan kimia (chemical resistant) yang baik. Selain material pengikat (matrik) komposit juga mengunakan material penguat atau pengisi (filler), material penguat ini biasanya mengunakan serat, dengan sifat serat yang kuat, kaku dan getas. Hal ini ditujukan agar serat dapat menahan gaya dari luar. Serat pada dasarnya dibagi menjadi dua yaitu serat alami (natural fiber) dan serat buatan (syntethic fiber). Serat banyak dimanfaatkan di dunia perindustrian, seperti prabrik pembuat tali, industri tektil, industri kertas, karena mempunyai kekuatan yang tinggi, serat sangat baik untuk material komposit.

Serat alami sekarang banyak digunakan karena jumlahnya banyak dan sangat murah jadi sering dimanfaatkan sebagai material penguat seperti serat jute, kenaf, abaca, rosella, jerami dan masih banyak serat alami yang lain yang biasa dimanfaatkan, akan tetapi serat alami mempunyai kekuatan yang rendah dibandingkan serat buatan. Sedangkan serat buatan jarang digunakan karena selain jarang ditemukan dan nilai belinya sangat mahal jadi sangat jarang digunakan, seperti E glass, nilon, serat protein, fenol dan masih banyak lainnya. Dalam penelitian ini bahan utama yang akan digunakan yaitu bahan pengikat (matrik) mengunakan Thermosetting yang jenisnya resin epoksi karena bahan tersebut mempunyai ketahanan bahan kimia yang sangat baik dan mempunyai kekuatan yang sangat tinggi, sedangkan bahan pengisinya (filler) mengunakan serat nilon dikarenakan bahan tersebut menpunyai kekuatan yang tinggi dan mempunyai ketahanan yang baik terhadap bahan kimia dan panas. Tujuan dari penelitian ini yaitu untuk mengetahui kekuatan bending komposit berpenguatan serat nilon dengan matrik resin epoxy.

\section{Dasar teori}

\section{Bahan Komposit}

Menurut Gibson (1994) komposit adalah sruktur material yang terdiri dari 2 kombinasi bahan atau lebih, yang dibentuk pada skala makroskopik dan menyatu secara fisika. Menurut Diharjo (1999), kata komposit dalam pengertian bahan komposit berarti terdiri dari dua mengemukakan bahwa kata komposit (composite) merupakan kata sifat yang berarti susunan atau gabungan.Composite berasal dari kata kerja "to compose" yang berarti menyusun atau menggabung. Jadi secara sederhana bahan komposit berarti bahan gabungan dari dua atau lebih bahan yang berlainan. 


\section{Faktor Yang Mempengaruhi Performa komposit}

Penelitian yang mengabungkan antara matrik dan serat harus memperhatikan beberapa faktor yang mempengaruhi performa Fiber-Matrik Composites antara lain:

\section{Faktor Serat}

Serat adalah bahan pengisi matrik yang digunakan untuk dapat memperbaiki sifat dan struktur matrik yang tidak dimilikinya, juga diharapkan mampu menjadi bahan penguat matrik pada komposit untuk menahan gaya yang terjadi.

\section{Letak Serat}

Dalam pembuatan komposit tata letak dan arah serat dalam matrik yang akan menentukan kekuatan mekanik komposit, dimana letak dan arah dapat mempengaruhi kinerja komposit tersebut. Pada pencampuran dan arah serat mempunyai beberapa keunggulan, jika orientasi serat semakin acak ( random ) maka sifat mekanik pada 1 arahnya akan melemah, bila arah tiap serat menyebar maka kekuatannya juga akan menyebar kesegala arah maka kekuatan akan meningkat.

\section{Panjang Serat}

Ada 2 penggunaan serat dalam campuran komposit yaitu serat pendek dan serat panjang. Serat panjang lebih kuat dibanding serat pendek. Panjang serat berbanding diameter serat sering disebut dengan istilah aspect ratio. Bila aspect ratio makin besar maka makin besar pula kekuatan tarik serat pada komposit tersebut. Serat panjang (continous fiber) lebih efisien dalam peletakannya daripada serat pendek. Akan tetapi, serat pendek lebih mudah peletakannya dibanding serat panjang. Panjang serat mempengaruhi kemampuan proses dari komposit serat. Pada umumnya, panjang serat lebih mudah penanganannya jika dibandingkan dengan serat pendek.

\section{Bentuk Serat}

Bentuk Serat yang digunakan untuk pembuatan komposit tidak begitu mempengaruhi, yang mempengaruhi adalah diameter seratnya. Pada umumnya, semakin kecil diameter serat akan menghasilkan kekuatan komposit yang lebih tinggi. Selain bentuknya kandungan seratnya juga mempengaruhi (Schwartz, 1984 :1.4).

5. Faktor Matrik

Matrik dalam komposit berfungsi sebagai bahan mengikat serat menjadi sebuah unit struktur, melindungi dari perusakan eksternal, meneruskan atau memindahkan beban eksternal pada bidang geser antara serat dan matrik, sehingga matrik dan serat saling berhubungan. Pembuatan komposit serat membutuhkan ikatan permukaan yang kuat antara serat dan matrik.

6. Faktor Ikatan Fiber-Matrik
Hal yang mempengaruhi ikatan antara serat dan matrik adalah void, yaitu adanya celah pada serat atau bentuk serat yang kurang sempurna yang dapat menyebabkan matrik tidak akan mampu mengisi ruang kosong pada cetakan. Bila komposit tersebut menerima beban, maka daerah tegangan akan berpindah ke daerah void sehingga akan mengurangi kekuatan komposit tersebut.

7. Katalis

Katalis ini digunakan untuk membantu proses pengeringan resin dan serat dalam komposit. Waktu yang dibutuhkan resin untuk berubah menjadi plastik tergantung pada jumlah katalis yang dicampurkan. Semakin banyak katalis yang ditambahkan maka makin cepat pula proses curingnya. Tetapi apabila pemberian katalis berlebihan maka akan menghasilkan material yang getas ataupun resin bisa terbakar.

\section{Serat Nilon}

Serat nilon mempunyai beberapa keunggulan tersendiri yaitu :

1. Sifat mekanis

Nilon mempunyai sifat mekanis yang unggul dalam kekuatan tarik dan kekuatan impact, nilon juga termasuk golongan ketahanan abrasi dan pelumasan yang paling mengguntungkan di antara berbagai jenis resin.

2. Sifat kimia

Bahan ini tidak larut dalam alkohol, alkali, eter, hidrokarbon dan deterjen, tetapi larut dalam fenol dan asam format. Nilon tidak dapat melewatkan oksigen, nitrogen, gas karbon dioksida dan sebagainya.

3. Kemampuan cetak

Karena polimer bersifat kristalin, temperatur pelunaknya berdaerah sempit, dan mempunyai kalor pelelehnya yang tinggi. Karena viskositas lelehnya tergantung temperatur, maka temperatur harus di kontrol ketat.

\section{Pengunaannya}

Kebanyakan bahan komposit yang digunakan dalam bentuk serat, bahan ini massa jenisnya kecil, koefisien gesek sangat tinggi, kekuatan tekuk dan kekuatan simpul tinggi dan kepermanenan yang baik. Sebagian serat industri nilon banyak digunakan komponen mobil, kompomen mesin umum, alat-alat olahraga dan masih banyak lagi.

\section{Matrik epoxy}

Resin epoksi merupakan jenis resin termoset. Resin epoksi mempunyai kegunaan yang luas dalam industri kimia teknik, listrik, mekanik, dan sipil sebagai bahan perekat, cat pelapis, dan benda-benda cetakan. Selain itu mempunyai kekuatan yang tinggi, resin epoksi juga mempunyai ketahanan kimia yang baik. Bahan resin epoksi diproduksi oleh PT. Justus Kimia Raya, Semarang.

\section{Pengujian Bending}


Untuk mengetahui kekuatan bending suatu material dapat dilakukan dengan pengujian bending terhadap material komposit tersebut. Kekuatan bending atau kekuatan lengkung adalah tegangan bending terbesar yang dapat diterima akibat pembebanan luar tanpa mengalami deformasi yang besar atau kegagalan. Besar kekuatan bending tergantung pada jenis material dan pembebanan. Akibat Pengujian bending, bagian atas spesimen mengalami tekanan, sedangkan bagian bawah akan mengalami tegangan tarik. Dalam material komposit kekuatan tekannya lebih tinggi dari pada kekuatan tariknya. Karena tidak mampu menahan tegangan tarik yang diterima, spesimen tersebut akan patah, hal tersebut mengakibatkan kegagalan pada pengujian komposit. Kekuatan bending pada sisi bagian atas sama nilai dengan kekuatan bending pada sisi bagian bawah. Pengujian dilakukan three point bending.

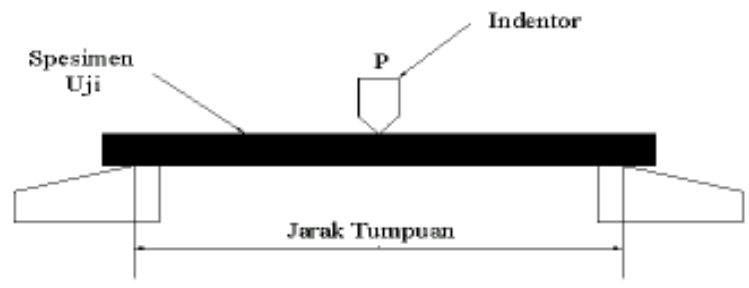

Gambar 1. Pemasangan benda uji

Sehingga kekuatan bending dapat dirumuskan sebagai berikut :

$$
\begin{gathered}
\sigma_{b}=\frac{P L / 4 \times 1 / 2 d}{b x d / 12} \\
\sigma_{b}=\frac{12 P L d}{8 b d^{3}} \\
\sigma_{b}=\frac{3 P L}{2 b d^{2}}
\end{gathered}
$$

Pada perhitungan kekuatan bending ini, digunakan persamaan yang ada pada standar ASTM D790, sama seperti pada persamaan di atas, yaitu:

$$
S=\frac{3 P L}{2 b \cdot d^{2}}
$$

Dimana;

$\mathrm{S}=$ Tegangan bending $(\mathrm{MPa}), \mathrm{P}=\operatorname{Beban} / \operatorname{Load}(\mathrm{N}), \mathrm{L}$ = Panjang Span / Support span $(\mathrm{mm}), \mathrm{b}=$ Lebar/ Width $(\mathrm{mm}), \mathrm{d}=$ Tebal $/$ Depth $(\mathrm{mm})$, Sedangkan untuk mencari modulus elastisitas bending mengunakan rumus

$$
E_{b}=\frac{L^{3} m}{4 b d^{3}}
$$

Dimana; Eb = Modulus Elastisitas Bending (MPa), L = Panjang Span $/$ Support span $(\mathrm{mm}), \mathrm{b}=$ Lebar/ Width $(\mathrm{mm}), \mathrm{d}=$ Tebal $/$ Depth $(\mathrm{mm}), \mathrm{m}=$ Slope Tangent pada kurva beban defleksi $(\mathrm{N} / \mathrm{mm})$.

\section{Metodologi Penelitian}

Bahan-bahan yang digunakan dalam proses pembuatan komposit, yaitu:

1. Serat, serat yang digunakan adalah serat nilon yang dipotong sebesar $12 \mathrm{~mm}$. Bahan nilon yang digunakan dalam penelitian berbentuk benang sol sepatu dengan diameter $0,5 \mathrm{~mm}$.

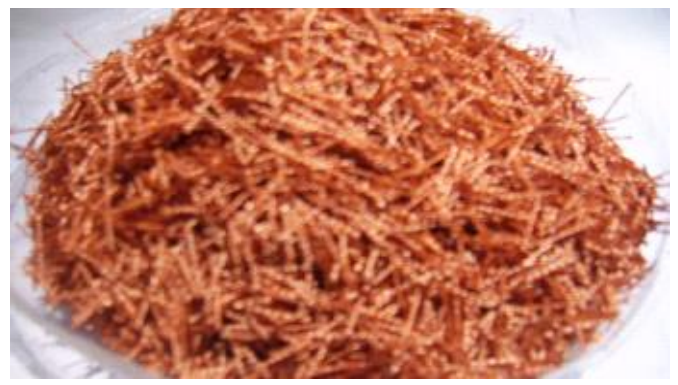

Gambar 3. Serat nilon

2. Campuran epokxy resin diperoleh dari PT. Justus Sakti Raya, cabang semarang. 3. MEKPO (Methyle Ethyl Ketone Peroxide). Proses curing dengan MEKPO membutuhkan waktu 8-12 jam.

\section{Proses Pencetakan}

Langkah-langkah pencetakan spesimen komposit ini dimana cetakan dibuat dari kaca, yaitu:

1. Langkah pertama yaitu menuangkan resin dan katalis sesuai perhitungan yang telah ditentukan kedalam gelas ukur. Aduk campuran tersebut hingga rata. 2. Tuangkan campuran resin dan katalis kedalam cetakan secukupnya, kemudian ratakan hingga semua daerah cetakan terisi. 3. Masukkan perlahan-lahan sebagian serat kedalam cetakan kemudian siram serat dengan resin. Ratakan dan tekan serat dengan pengaduk supaya distribusinya merata. 5. Masukkan sisa serat kedalam cetakan. Setelah itu siram kembali serat dengan resin yang tersisa. Ratakan dan tekan kembali serat dengan pengaduk supaya distribusinya merata. 6. Tutup cetakan dengan kaca kemudian tekanlah/press dengan balok. Tunggu selama 12 jam sampai cetakan mengering/mengeras.

\section{Pembuatan Spesimen}

Bentuk Spesimen uji bending komposit mengacu pada standar ASTM C393, dimana 
mempunyai dimensi panjang $=100 \mathrm{~mm}$ dan lebar $=30$ $\mathrm{mm}$.

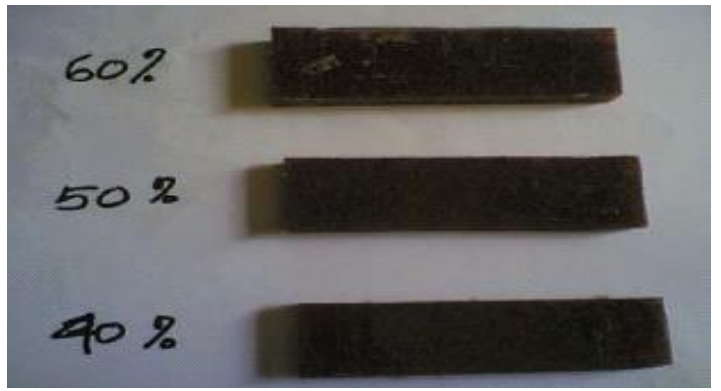

Gambar 4. Spesimen uji bending komposit

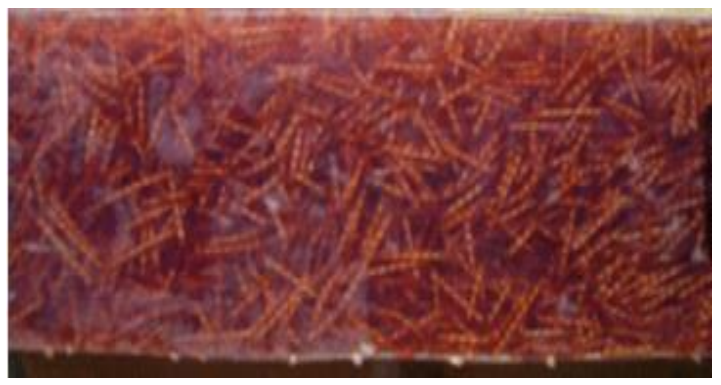

Gambar 5. Bentuk ikatan serat dan matrik

Dalam penelitian ini yang menjadi variabel bebas adalah fraksi volume serat yaitu $40 \%, 50 \%$, $60 \%$, dimana setiap pengujian dilakukan 3 kali pengulangan.

\section{Hasil dan Pembahasan}

Didalam penelitian ini untuk menentukan besarnya momen yang dihasilkan, berdasarkan pada pengujian three point bending digunakan rumus $1 / 2 \mathrm{P}$. $1 / 2 \mathrm{~L}$ atau 1/4 P.L. Dari hasil pengujian bending dengan mesin Torsee terhadap komposit didapatkan grafik hubungan tegangan (MPa) dengan fraksi volume dan grafik hubungan momen ( $\mathrm{MPa}$ ) dengan fraksi volume serat, seperti yang diperlihatkan dalam gambar 6 dan gambar 7 .

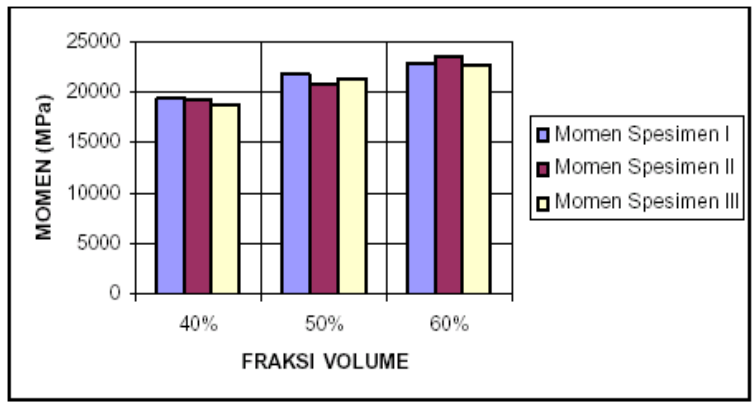

Gambar 6. Grafik momen dan fraksi volume

Pada gambar 6, menunjukkan bahwa momen rata-rata pada komposit dengan fraksi volume $40 \%$ mempunyai nilai sebesar 19093 Nmm lebih rendah dari pada komposit dengan fraksi volume $50 \%$ yaitu sebesar $21306 \mathrm{Nmm}$ sedangkan untuk komposit dengan fraksi volume $60 \%$ lebih tinggi lagi dibanding komposit volume $50 \%$ dan komposit fraksi volume 40 $\%$ yaitu sebesar $23038 \mathrm{Nmm}$. Komposit dengan fraksi volume $40 \%$ lebih mudah retak, hal ini disebabkan banyaknya resin yang serat tersebut mengikat sehingga pada volume komposit ini mudah retak dibanding komposit yang mempunyai fraksi volume $50 \%$, komposit volume $50 \%$ itu sendiri tidak mengalami keretakan disebabkan adanya ikatan serat dan resin yang seimbang sehingga komposit tersebut cuma mengalami kelenturan saja. Sedangkan untuk komposit volume 60 mengalami keretakan yang hampir sama dengan komposit volume $40 \%$ dikarenakan adanya antara resin dan serat.

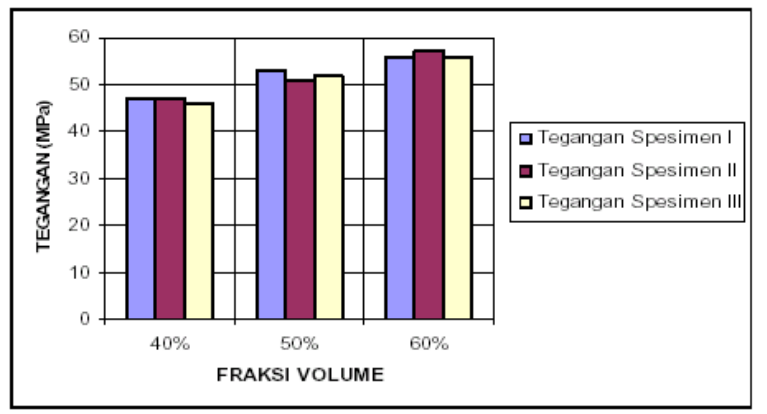

Gambar 7. Grafik tegangan bending vs fraksi volume serat

Pada gambar 7, menunjukkan bahwa kenaikan tegangan dikarenakan penambahan seratnya, grafik tersebut menjelaskan semakin tinggi fraksi volume seratnya maka tegangan semakin tinggi, hal ini ditunjukkan pada fraksi volume $40 \%$ besarnya tengangan bending yaitu 47,14 $\mathrm{MPa}$, lebih kecil dibanding fraksi volume $50 \%$ yang sebesar 52,60 MPa. Sedangkan untuk fraksi volume $60 \%$ besarnya tegangan 56,88 $\mathrm{MPa}$, yang lebih tinggi dari fraksi volume $40 \%$ dan fraksi volume $50 \%$. Dari hasil diatas menunjukkan bila serat semakin banyak serat maka tegangan bendingnya semakin naik. Semakin meningkatnya kekuatan bending ini dikarenakan dimensi komposit yang semakin besar. Semakin banyak serat yang digunakan, dimensi komposit akan semakin besar pula. Hal ini disebabkan komposit yang semakin banyak seratnya tengangan bendingnya semakin melemah karena komposit Cuma bertumpu pada serat saja, bila semakin bertambahnya serat, secara otomatis mengurangi bahan pengikatnya yang menyebabkan ikut melemahnya pula bahan pengikat tersebut. 


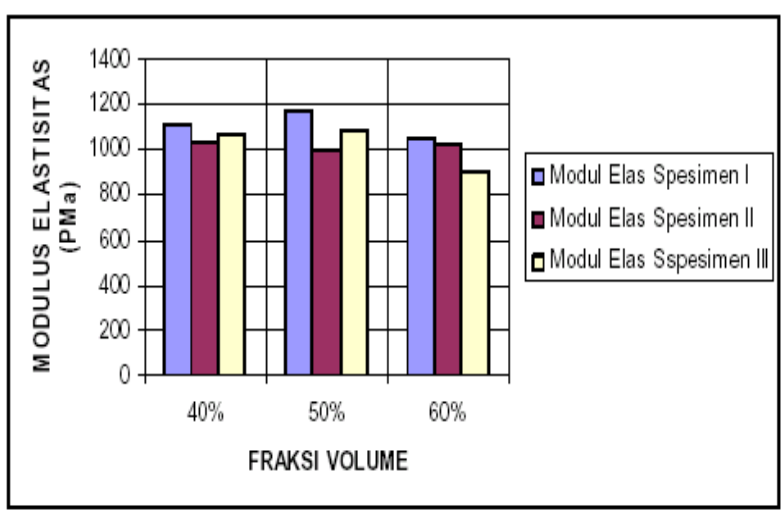

Gambar 8. Grafik modulus elastisitas bending

Selanjutnya pada gambar 8, menunjukkan bahwa besarnya nilai modulus elastisitas (GPa) komposit serat nilon dan resin epoksi dengan variasi fraksi volume $40 \%$, fraksi folume $50 \%$ dan fraksi volume $60 \%$. Dari grafik hubungan antara modulus elastisitas (GPa) serat nilon dan resin epoksi diatas, dapat diketahui bahwa pada komposit tersebut dengan fraksi volume $40 \%$ memiliki modulus elastisitas rata-rata sebesar 1,069 GPa, sedangkan fraksi volume $50 \%$ menpunyai modulus elastisitas rata-rata sebesar 1,085 $\mathrm{GPa}$, dan fraksi volume $60 \%$ mempunyai modulus elastisitas rata-rata sebesar 0,99 GPa. Secara umum dari grafik hubungan antara modulus elastisitas $(\mathrm{GPa})$ dengan fraksi volume (\%) serta berbagai uraian diatas, dapat diperoleh kesimpulan bahwa besarnya nilai modulus elastisitas pada komposit serat nilon dan resin epoksi dengan variasi fraksi volume $40 \%, 50 \%$, $60 \%$ meningkat dari fraksi volume $40 \%$ ke $50 \%$, sedangkan dari fraksi volume $50 \%$ ke $60 \%$ mengalami menurun secara signifikan seiring dengan bertambahnya serat yang dicampurkan. Bentuk patahan spesimen hasil pengujian bending diperlihatkan gambar 9 dan 10.

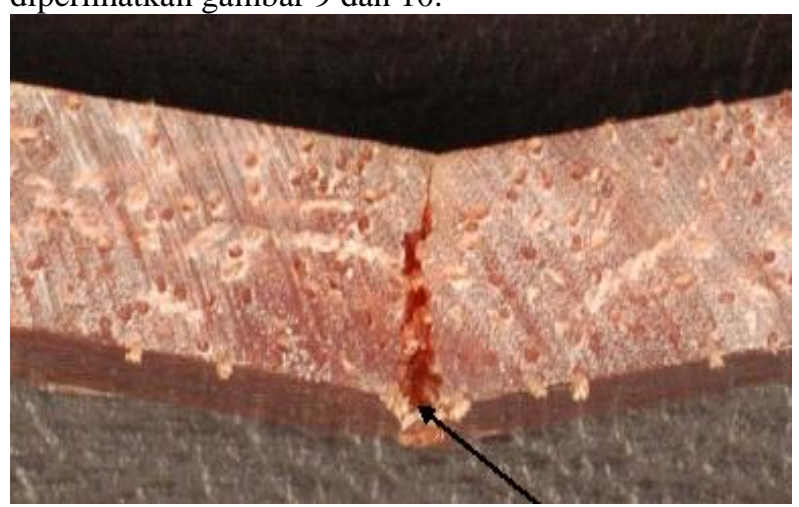

Awal retak

Gambar 9. Kegagalan pada pengujian bending komposit dengan fraksi volume $40 \%$

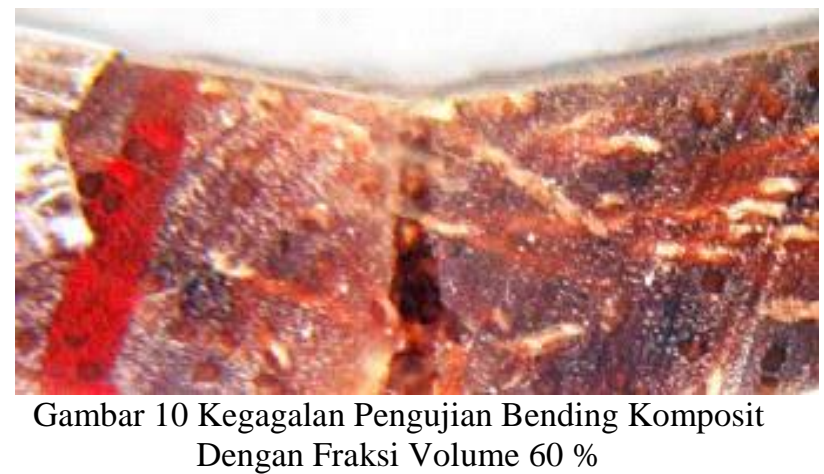

Pada gambar 9 dan 10, menunjukkan kegagalan pada pengujian bending komposit, dimana patahan terjadi dibagian bawah yang awal mulanya mengalami retak atau lepas dari ikatannya terhadap serat didalamnya. Pada umumnya kelemahan komposit terhadap beban bending terletak pada bagian komposit yang belum merata pemampatannya antara serat dan resinnya dibagian bawah pada spesimen. Pada lapisan ini mempunyai kekuatan tarik maksimum dan akan mengalami kegagalan paling awal karena tidak mampu menahan tegangan tarik pada bagian bawah komposit, sehingga akan terjadi retak lebih awal. Kekuatan yang menahan beban maksimum terjadi pada bagain komposit yang ada didalamnya, yang banyak terjadi pencampuran antara serat dan resin secara merata. Setelah dibagian dalamnya tidak mampu menahan beban maka di bagian bawah tidak mampu menahan beban, maka akan terjadi retakan pada bagain bawah spesimen tersebut, dan merupakan retakan awal pada komposit. Setelah bagian bawah patah, kekuatan menahan beban menurun drastis.

\section{Kesimpulan}

Berdasarkan pada analisa dan perhitungan dari data-data yang diperoleh dari hasil pengujian maka dapat diambil suatu kesimpulan yaitu Kekuatan bending komposit serat nilon dan matrik resin epoksi tertinggi pada variasi fraksi volume $60 \%$ yaitu sebesar $57,95 \mathrm{MPa}$. Kekuatan bending komposit meningkat pada variasi fraksi volume $40 \%, 50 \%, 60 \%$ sebesar $11,7 \%$, yaitu 46,21-57,95 MPa. Modulus elastisitasnya menurun dari fraksi volume $40 \%, 50 \%$, $60 \%$ sebesar 7,9 \% dari 1069-990 MPa.

\section{Daftar Pustaka}

Annual Book of ASTM Standards, D 3379- 75,1990. "Standard Test Method for Tensile Strength and Young's Modulus Single-Filament Materials", ASTM Standards and Literature References for Composite Materials, 2nd ed., 34-37, American Society for Testing and Material, Philadelphia. 
Annual Book of JIS Standards, K 7113, 396-407, 1981. "Testing Method for Tensile Properties of

Plastik", Japanese Industrial Standard.

Diharjo, K., 2006, "Pengaruh Perlakuan Alkali terhadap Sifat Tarik Bahan Komposit Serat Rami-

Polyester”, Jurnal Teknik Mesin, Vol. 8, 8-13.

Gibson, F.R., 1994, Principle of Composite Material Mechanis, International Edition, McGraw- Hill, Inc., New York.

Mishra S.C. 2009. "Low cost polymer composites with rural resources", Journal of reinforced plastics and composites. Vol.28, No. 18, 2183-2188.

Nasmi H.S., 2010. Pengaruh panjang serat pandannus amaryllifolius terhadap kekuatan bending komposit polyester. Kemajuan Riset dan Teknologi yang ramah lingkungan. Seminar Nasional Teknik Mesin, Fakultas Teknik Universitas Mataram, ISBN 978- 602-8373-06-7.

Nasmi H.S., 2009, "Uji kekuatan tarik dan uji bending komposit polyester di perkuat dengan kain sisa/perca". Jurnal Oryza, Vol. VIII, 35-44.

Purboputro, P., 2005, "Pengaruh Panjang Serat Terhadap Kekuatan Impact Komposit Enceng Gondok Dengan Matrik Polyester", Media Mesin., Vol. 7, 70-76.

Schwartz, M.M., 1984, Composite Materials Handbook, McGraw-Hill, Book Co., New York.

Wicaksono, A., 2006, "Karakterisasi Kekeuatan Bending Komposit Berpenguat Kombinasi Serat Kenaf Acak dan Anyam", Tugas Akhir

Teknik Mesin, Universitas Negeri Malang, Malang. 